\title{
Novel Models to Identify Census Tracts for Hepatitis C Screening Interventions
}

\author{
Thomas Ludden, PhD, Lindsay Shade, PA-C, Jeremy Thomas, MSW, \\ Brisa Urquieta de Hernandez, BUS, Sveta Mohanan, MD, Mark W. Russo, MD, \\ Michael Leonard, MD, Philippe J. Zamor, MD, Charity G. Patterson, PhD, and \\ Hazel Tapp, PhD
}

Background: Increased screening efforts and the development of effective antiviral treatments have led to marked improvement in hepatitis C (HCV) patient outcomes. However, many people in the United States are still believed to have undiagnosed HCV. Geospatial modeling using variables representing atrisk populations in need of screening for HCV and social determinants of health (SDOH) provide opportunities to identify populations at risk of HCV.

Methods: A literature review was conducted to identify variables associated with patients at risk for HCV infection. Two sets of variables were collected: HCV Transmission Risk and SDOH Level of Need. The variables were combined into indices for each group and then mapped at the census tract level $(n=233)$. Multiple linear regression analysis and the Pearson correlation coefficient were used to validate the models.

Results: A total of $4 \mathrm{HCV}$ Transmission Risk variables and 12 SDOH Level of Need variables were identified. Between the 2 indexes, 21 high-risk census tracts were identified that scored at least 2 standard deviations above the mean. The regression analysis showed a significant relationship with HCV infection rate and prevalence of drug use $(B=0.78, P<.001)$. A significant relationship also existed with the HCV infection rate for households with no/limited English use $(B=-0.24, P=.001)$, no car use $(B=0.036, P<.001)$, living below the poverty line $(B=0.014, P=.009)$, and median household income $(B=-0.00, P=.009)$.

Conclusions: Geospatial models identified high-priority census tracts that can be used to map highrisk HCV populations that may otherwise be unrecognized. This will allow future targeted screening and linkage-to-care interventions for patients at high risk of HCV. (J Am Board Fam Med 2020;33:407-416.)

Keywords: Hepatitis C, Regression Analysis, Risk Factors, Social Determinants of Health

\section{Background}

Hepatitis $\mathrm{C}$ virus (HCV) is a potentially devastating disease that adversely affects quality of life and

This article was externally peer reviewed.

Submitted 30 August 2019; revised 12 December 2019; accepted 3 January 2020.

From Department of Family Medicine, Atrium Health, Charlotte, NC (TL, LS, JT, SM, HT); Department of Hepatology, Atrium Health, Charlotte, NC (MWR, PJZ); Department of Infectious Diseases, Atrium Health, Charlotte, NC (ML); Community Health, Atrium Health, Charlotte, NC (BUH); School of Health and Rehabilitation Sciences, University of Pittsburgh, Pittsburgh, PA (CGP).

Funding: This study, IN-US-337-4324, is supported by Gilead Sciences, Inc.

Conflicting and Competing Interests: None

Corresponding author: Thomas Ludden, $\mathrm{PhD}$, Department of Family Medicine, Atrium Health, 2001 Vail Avenue, Suite 400B, Charlotte, NC 28207 (E-mail: Tom.Ludden@ atriumhealth.org). increases premature mortality. An estimated 2.4 million people have chronic $\mathrm{HCV}$ in the United States. Of those people with chronic HCV, 75\% are unaware that they are infected. ${ }^{1-3}$ Half of the cases are related to intravenous drug use and the remainder from sexual contact, tattoos, vertical transmission from birth mother to child, intranasal drug use with shared paraphernalia, biologic products such as contaminated blood or transplants, and medical procedures. ${ }^{4-6}$ "Baby Boomers," patients born between 1945 and 1965, were likely infected between 1960 and 1980 and account for the majority of all chronic $\mathrm{HCV}$ infections in adults. The Centers for Disease Control and Prevention recommends a one-time HCV blood test for all adults born between 1945 and 1965 to screen for the disease and prevent HCV spread. ${ }^{4,7-9}$ 
Screening efforts and the development of effective antiviral treatments have led to improvements in HCV patient outcomes. ${ }^{10}$ Observational studies demonstrate a $40 \%$ reduction in hepatocellular carcinoma and liver failure in patients who achieve virologic cure, along with a reduction in mortality rates. ${ }^{11-14}$ Patient experience a $5 \%$ to $20 \%$ increased risk for liver cirrhosis due to delayed treatment, putting patients at high risk for additional complications, such as hepatocellular carcinoma. ${ }^{10}$ In 2016, over 18,000 people had HCV as an underlying cause of death. ${ }^{15}$ Moreover, nearly $42 \%$ of primary care physicians reported being unfamiliar with the Centers for Disease Control and Prevention guidelines for HCV screening in a survey of community-based physicians. ${ }^{16}$

Many factors cause delays in the screening and treatment of patients with $\mathrm{HCV}$. Because social determinants of health $(\mathrm{SDOH})$ play a role in overall health outcomes and, therefore, may lead to delays in screening and treatment, developing solutions to increase HCV screening requires an understanding of the underlying $\mathrm{SDOH}$ variables that are correlated with $\mathrm{HCV}$ infection rates and affect decision making around screening and treatment of HCV. ${ }^{17-19}$ Known SDOH variables can be used to identify patients who would benefit from interventions to reduce the delay in screening and treatment. Although some electronic health records (EHRs) are building the capacity to capture $\mathrm{SDOH}$ variables to provide service options to patients, this information is not yet consistently captured.

One method to efficiently and effectively identify patients with SDOH is by geographically mapping known SDOH variables and indexing the data at the census tract level. ${ }^{17}$ Previous work used Geographic Information System mapping combined with participatory research techniques to look at areas in a community most in need of access to primary care services. ${ }^{20}$ Maps were created using SDOH and community-level attributes to identify geographic regions most in need of access to health care services. Results of SDOH mapping were used to develop and implement interventions around patient populations impacted by $\mathrm{SDOH}$ to increase access to primary care services with the intent to improve screenings and reduce time to treatment. ${ }^{21-23}$

Here, we show how patient $\mathrm{HCV}$ characteristics and SDOH variables can be mapped both individually and in combination to identify patient populations most in need of interventions to screen and treat for $\mathrm{HCV}$. Patients diagnosed with $\mathrm{HCV}$ and $\mathrm{SDOH}$ variables can be mapped out at the census tract level to identify priority patient populations that overlap with high index values of $\mathrm{SDOH}$ variables pertinent to $\mathrm{HCV}$.

The objectives of this article are to (1) identify the variables that correlate with the HCV transmission risk, (2) identify the SDOHs that are barriers to screening and treating patients with $\mathrm{HCV}$, (3) identify high-priority census tracts to identify patients and practices for screening interventions for $\mathrm{HCV}$, and (4) validate the results of the of the $\mathrm{HCV}$ and SDOH models. We hypothesized that overlap would occur between the census tracks with high risk for HCV transmission and high index values of SDOH variables, identifying priority areas associated with at-risk patient populations.

\section{Methods}

The literature was reviewed to identify the most common variables associated with HCV transmission and $\mathrm{SDOH}$ that are related to the screening and treatment of HCV patients., 24-27 The literature review was conducted until we reached saturation and did not find any additional variables. HCV and SDOH variables identified by the literature review were presented to the Social and Economic Team (SET) committee, a project advisory board composed of representatives from a large health care system that includes representation from behavioral health, primary care, social work, case management, human resources, virtual care, quality, and research.

In establishing the working relationship with the SET, we leveraged completed work that was used for a report evaluating SDOH needs pertinent to access health care and a website, ${ }^{28}$ including $\mathrm{SDOH}$ variables in the following indicator categories: general population, economic, housing and transportation, social resources and education, and food access (Table 1). Although these variables were not specific to HCV, they represented the collective input by the committee to systematically identify the SDOH variables that were representative of the patients seeking health care in the Charlotte, NC, region. ${ }^{28}$

From the list of identified variables, data were collected from publicly available sources and from the EHR from Atrium Health (formerly Carolinas 
Table 1. Variables Identified by a Literature Review and the Social and Economic Team Committee Associated with Hepatitis C Transmission Risk and Social Determinants of Health Level of Need

\begin{tabular}{|c|c|}
\hline & Variable Name \\
\hline Literature Review & $\begin{array}{l}\text { Social and Economic Team } \\
\text { Committee }\end{array}$ \\
\hline Low income & $\begin{array}{l}\text { Individuals with less than a high school } \\
\text { education }\end{array}$ \\
\hline Racial minorities & Households with no/limited English \\
\hline $\begin{array}{l}\text { Poor access to } \\
\text { healthcare } \\
\text { services }\end{array}$ & Single parent households \\
\hline Injection drug use & Low access to food sources \\
\hline $\begin{array}{l}\text { Baby Boomer } \\
\text { birth cohort }\end{array}$ & Median household income \\
\hline $\begin{array}{l}\text { Uninsured/ } \\
\text { under-insured/ } \\
\text { publicly insured }\end{array}$ & Unemployed individuals \\
\hline Homelessness & Households living in rental housing \\
\hline $\begin{array}{l}\text { Current or history } \\
\text { of incarceration }\end{array}$ & $\begin{array}{l}\text { Households paying }>30 \% \text { of income } \\
\text { for rent } \\
\text { Households without transportation } \\
\text { Crowded households ( }>1 \text { person per } \\
\text { room) }\end{array}$ \\
\hline
\end{tabular}

HealthCare System), an integrated health care system based in Charlotte, with over 12 million patient encounters per year. The percentage of the population for each census tract that were patients with Atrium Health ranged from $13 \%$ to $96 \%$ with an average of $56 \%$. Across the system, approximately $57 \%$ of patients seen identify as female; $70 \%$ are white and 19\% African American; 15\% are 70+ years old, $26 \%$ are between the ages of 50 and 69 years, $34 \%$ are between 20 and 49 years of age, and $25 \%$ are 19 years old or younger; payer mix is $16 \%$ Medicare, 15\% Medicaid, 49\% commercial, and $20 \%$ self pay or other.

Data were coded to correspond to census tracts in Mecklenburg County, NC. The variables were then mapped out and reviewed by the research team and SET. The mapped values were standardized and then combined into 2 groups: HCV Transmission Risk and SDOH Level of Need. Using these 2 index maps, we identified priority areas using risk variables mapped at the census tract level in Mecklenburg County, NC, to identify census tracts associated with at-risk patient populations for HCV and SDOH. ArcGIS 10.5.1 (Environmental Research Institute, Redlands,
CA) was used to create maps to identify patients in priority census tracts.

The SET reviewed the results of the geospatial models based on the best evidence from the literature and qualitative assessments. The SET viewed the census tracts selected and agreed that, in their opinion and via previous impressions, these areas were likely to benefit from increased screening. The SET agreed that the identified areas were likely to have high rates of undiagnosed HCV based on known risk factors and should be used to target community outreach to increase HCV screening. ${ }^{20,22,23,29-31}$ The research team identified priority tracts, and draft maps were vetted again by the SET and providers within the health care system through key informant interviews.

\section{Statistical Methods}

HCV Transmission Risk and SDOH Level of Need indices were created using standardized values by calculating the mean and standard deviation for a variable. For each variable value for each census tract, the mean was subtracted and divided by the standard deviation to obtain the standardized score. The standardized scores for all variables for each census tract were then added together and divided by the number of variables to get an average standardized variable. The summarized index score was then again standardized. Multiple linear regression analysis was used to validate the results of the HCV Transmission Risk Index and SDOH Level of Need Index. A Pearson correlation coefficient was computed to assess the relationship between $\mathrm{HCV}$ Transmission Risk and SDOH Level of Need. A $P$ value of $<0.05$ was considered significant. All analyses were conducted using R v3.43 (R Foundation for Statistical Computing, Vienna, Austria).

\section{Results}

The literature review identified 8 variables, and the SET included 10 additional variables related to $\mathrm{SDOH}$ based on previous projects evaluating variables in the environment associated with a wide range of health and quality of life outcomes. ${ }^{28}$

Two of the variables, incarcerated and homeless populations, were not included because they could not be mapped at the census tract level. Injection drug use was modified to drug use, as mode of delivery could not always be verified in the EHR. For the racial minority variable, we chose percent 
Table 2. Social Determinants of Health Variables Collected for Mecklenburg County, NC, Census Tracts Used to Identify Populations at Risk for Hepatitis C Infection

\begin{tabular}{|c|c|}
\hline Variable Name & Definition and Source \\
\hline Individuals with less than a high school education & $\begin{array}{l}\text { Percentage of individuals over the age of } 25 \text { who have not completed a } \\
\text { high school education* }\end{array}$ \\
\hline Households with no/limited English & $\begin{array}{l}\text { Percentage of households over the age of } 5 \text { who speak no or limited } \\
\text { English at home* }\end{array}$ \\
\hline Single-parent households & Percentage of households who have only 1 parent present in household* \\
\hline Low access to food sources & $\begin{array}{l}\text { Percentage of the population living more than } 1 / 2 \text { mile (urban areas) or } \\
\text { more than } 10 \text { miles (rural areas) from the nearest supermarket, } \\
\text { supercenter, or large grocery store }{ }^{\dagger}\end{array}$ \\
\hline Median household income & Median household income* \\
\hline Individuals living below the federal poverty line & Percentage of households living below the federal poverty line* \\
\hline Unemployed individuals & $\begin{array}{l}\text { Percentage of individuals ages } 16 \text { to } 64 \text { in the civilian labor force and not } \\
\text { employed divided by the number of individuals ages } 16 \text { to } 64 \text { in the } \\
\text { civilian labor force* }\end{array}$ \\
\hline Uninsured individuals & Percentage of individuals who do not have any form of health insurance* \\
\hline Households living in rental housing & Percentage of households living in rental housing* \\
\hline Households paying $>30 \%$ of income for rent & $\begin{array}{l}\text { Percentage of households who are paying greater than } 30 \% \text { of their } \\
\text { income in housing* }\end{array}$ \\
\hline Households without transportation & Percentage of households without access to a vehicle* \\
\hline Crowded households ( $>1$ person per room) & Percentage of households who have more than 1 person per room* \\
\hline
\end{tabular}

*US Census.

${ }^{\dagger}$ US Department of Agriculture.

white population and interpreted the results inversely. Of the remaining 16 variables collected at the census tract level, the variables were divided into SDOH variables $(\mathrm{n}=12)$ (Table 2$)$ and $\mathrm{HCV}$ Transmission Risk variables $(n=4)$ (Table 3$)$. Each set of variables was mapped and converted into an index score (Figure 1 and 2). Between the 2 indexes, 21 high-risk census tracts were identified that scored at least 2 standard deviations above the mean of 0 .

Table 3. Hepatitis C Transmission Risk Variables Collected for Mecklenburg County, NC, Census Tracts Used to Identify Populations at Risk for Hepatitis C Infection

\begin{tabular}{lc}
\hline Variable Name & Definition and Source \\
\hline $\begin{array}{c}\text { Percent Caucasian } \\
\text { population }\end{array}$ & $\begin{array}{c}\text { Caucasian population divided by total } \\
\text { population* } \\
\text { Percent of } \\
\text { population born } \\
\text { 1945-1965 }\end{array}$ \\
$\begin{array}{c}\text { Population born between 1945 and } \\
\text { Prevalence of drug divided by total population } \\
\text { use }\end{array}$ & $\begin{array}{c}\text { Number of patients who indicate they } \\
\text { currently or previously used drugs } \\
\text { divided by population }\end{array}$ \\
$\begin{array}{c}\text { Prevalence of } \\
\text { hepatitis C } \\
\text { infection }\end{array}$ & $\begin{array}{c}\text { Number of patients who have been } \\
\text { diagnosed with hepatitis C divided by } \\
\text { the total number of patients }\end{array}$ \\
\hline
\end{tabular}

*US Census.

${ }^{\dagger}$ Atrium Health, US Census.
Two census tracts overlapped between the 2 indexes; 11 were uniquely identified as priority tracts for HCV Transmission Risk by virtue of their scores for $\mathrm{HCV}$ prevalence, known percentage of drug use, Baby Boomer age cohort, and percentage of white persons in the census tracts. Eight were uniquely identified as priority tracts for $\mathrm{SDOH}$ Level of Need (Figure 3).

The location of the high priority tracts for the HCV Transmission Risk index mainly cluster around the center city, whereas the high-priority tracts for the SDOH Level of Need index are more dispersed around the center city.

\section{Data Validation of Results}

The linear regression analysis showed a significant relationship between the distribution of the $\mathrm{HCV}$ infection rate and patients reporting drug use (Table 4) (B=0.78, $P<.001)$. National trends indicate approximately $70 \%$ of new $\mathrm{HCV}$ cases are associated with intravenous drug users, and our results are also correlated with drug use regardless of delivery mode. ${ }^{32,33}$

The linear regression analysis showed that a significant relationship also existed with the $\mathrm{HCV}$ infection rate for households with no/limited English use (Table 5) $(\mathrm{B}=-0.24, P=.001)$, no car 
Figure 1. Hepatitis C transmission risk by census tract in Mecklenburg County, NC. Abbreviation: HCV, hepatitis C virus.

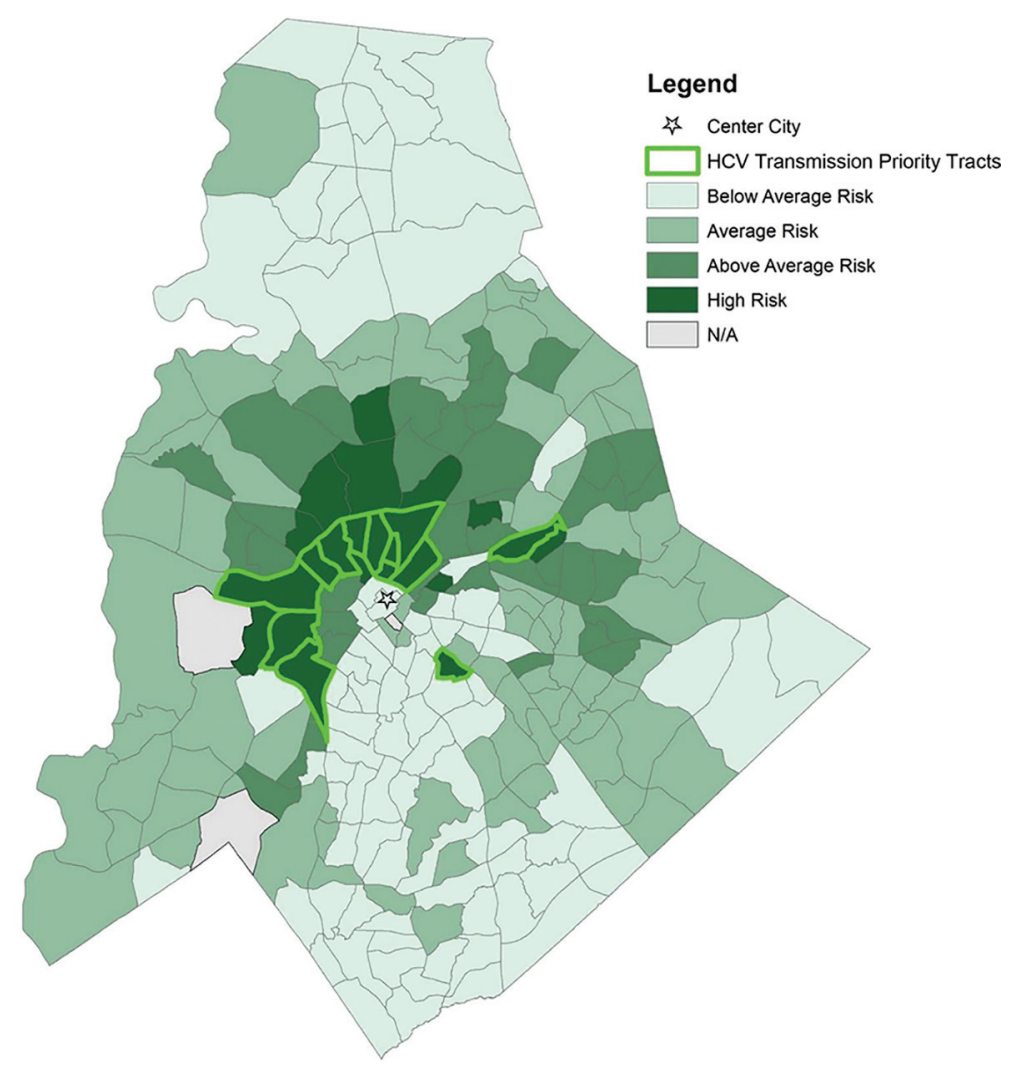

available $(\mathrm{B}=0.036, P<.001)$, living below the poverty line $(\mathrm{B}=0.014, P=.009)$, and median household income $(\mathrm{B}=-0.00, P=.009)$.

The Pearson correlation between the HCV Transmission Risk Index and the SDOH Level of Need Index showed a positive correlation, $(\mathrm{r}=0.62$, $\mathrm{n}=233, P<.001)$. Although the high-priority tracts between the 2 models did not overlap except for 2 census tracts, the correlation between the 2 indexes were relatively high. The results suggest that the SDOH Level of Need index provided a viable alternative to $\mathrm{HCV}$ Transmission Risk mapping for identifying neighborhoods for an intervention.

\section{Discussion}

Since many patients who are infected with HCV are unaware of their infection, screening patients in primary care provides an opportunity to identify these patients for linkage-to-care and treatment. In addition to the existing known variables, such as patients born between 1945 to 1965 and patients with current or past histories of drug use, other
SDOH factors can also be included to further identify high need areas to improve patient screening. Although the SDOH variables overlapped with the existing poverty and low-income variables used in the model, it was important to keep the broad range of variables originally selected by the SET. The results of this study show that the correlation between the HCV Transmission Risk and SDOH Level of Need is high. However, more research is needed to determine if additional screening criteria will enhance the number of patients diagnosed with HCV. ${ }^{4,34-38}$

With the increase in opioid drug use and drug injection users in the younger, suburban populations as well economically depressed rural areas, the epidemiology of HCV infection is changing. With the development of highly effective, welltolerated therapy, primary care providers may elect to diagnose and treat HCV. An understanding of how these patients were infected is important for determining who to screen and treat outside the existing Baby Boomer cohort. ${ }^{39}$ Although using $\mathrm{SDOH}$ variables will not 
Figure 2. Social Determinants of Health (SDOH) index indicating the level of need by census tract in Mecklenburg County, NC.

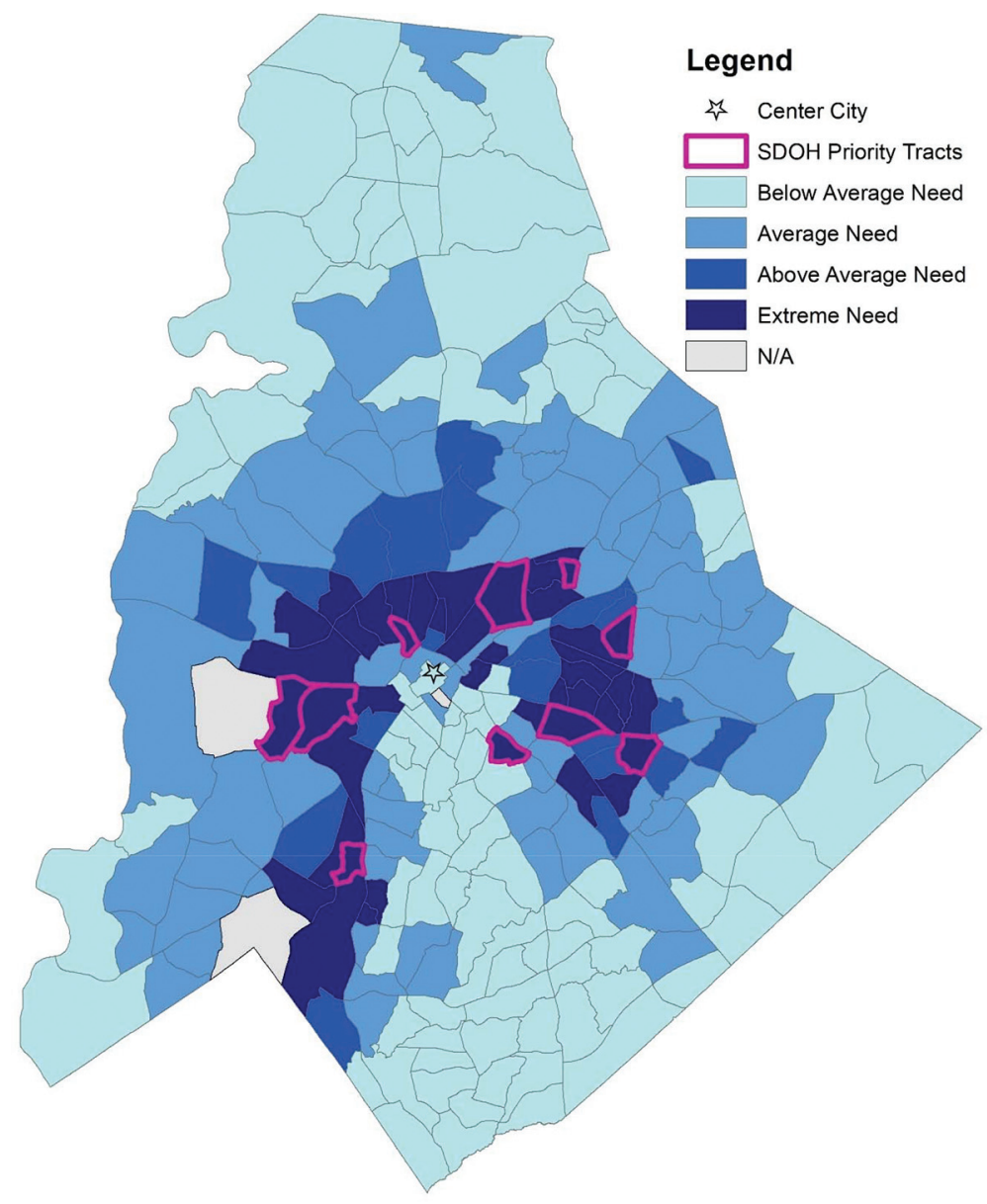

necessarily pick up suburban drug use, our results around the data validation of the $\mathrm{HCV}$ infection rate suggest that geographic areas outside the traditional center city that are challenged with both risks for HCV transmission and poor outcomes due to $\mathrm{SDOH}$ variables should not be excluded from future interventions.

Epidemiologic research has used geospatial models in many ways to identify at-risk patients with chronic diseases. A study in the United Kingdom used hot spot mapping for diabetic patients to identify potential patients in need of care. ${ }^{40}$ Other research has predicted the prevalence of certain diseases by using spatial regression models that accounted for additional environmental factors and longitudinal frequencies along with socioeconomics characteristics. ${ }^{40-43}$

\section{Future Research}

A future study objective is to identify patient populations that correspond with the high-risk census tracts identified here. By identifying these patient populations while acknowledging the sensitivity and cultural aspects of this type of research, the practices with the highest number of patients receiving care can receive educational interventions around screening and treatment of $\mathrm{HCV}{ }^{44-46}$ These interventions may also result in shorter duration of diagnosis to treatment of HCV. In addition to this proposed work, the next steps to establish index utility would be to screen in areas identified as low risk by using the same index and compare the results.

Because the United States Prevention Task Force now recommends screening for all adults aged 18 to 79 , future research should include the 18 
Figure 3. Hepatitis C transmission risk by census tract in Mecklenburg County, NC, with priority tracks from Social Determinants of Health (SDOH) Level of Need. Abbreviation: HCV, hepatitis C virus.

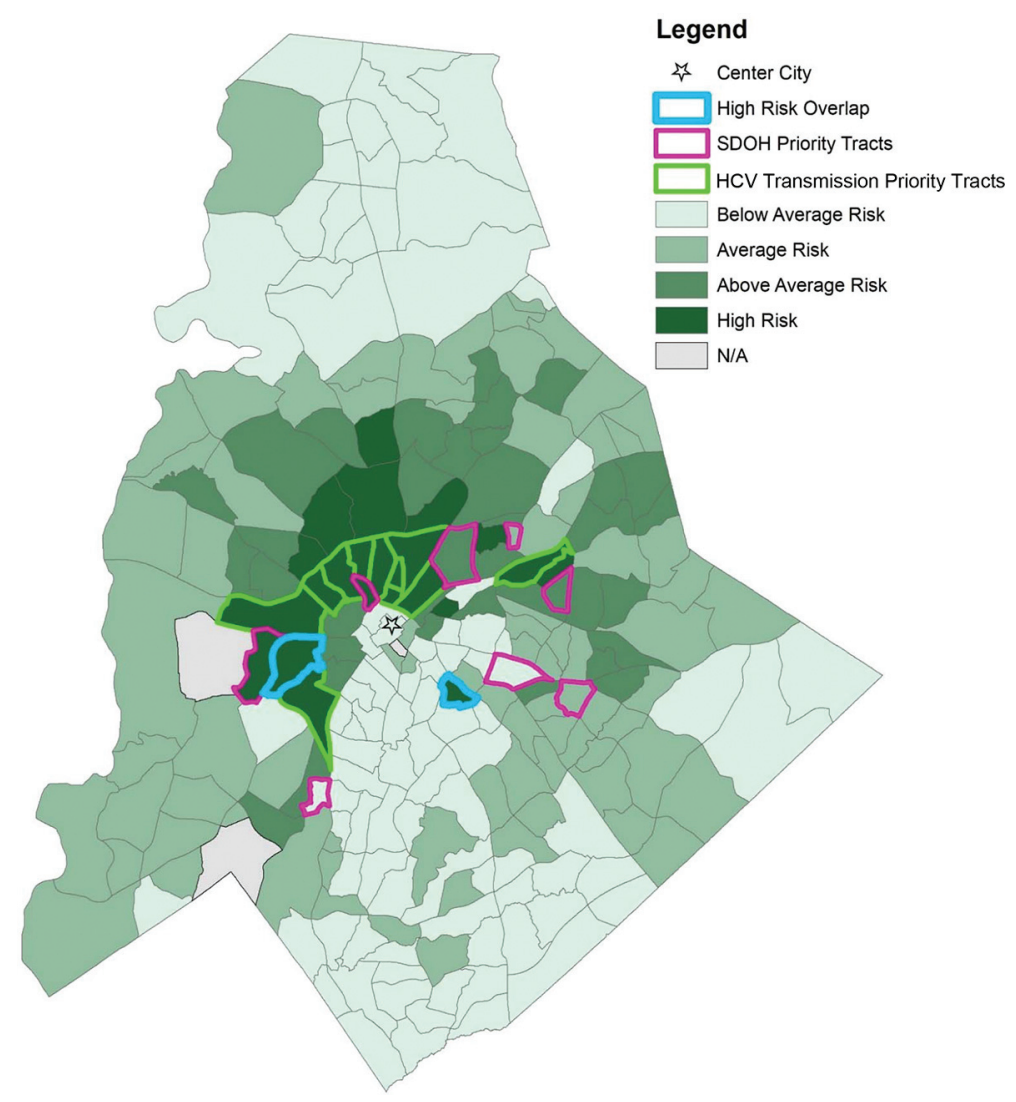

to 79 age range as the variable in the $\mathrm{HCV}$ Transmission risk model. ${ }^{47}$ To distinguish the difference in age groups, subgroups could be analyzed, such as 18 to 34,35 to 49 , and 50 to 79 , capturing

Table 4. Validation of the Hepatitis C Transmission Risk Index Using Multiple Linear Regression

\begin{tabular}{lcc}
\hline & \multicolumn{2}{c}{ Prevalence of Hepatitis C Infection } \\
\cline { 2 - 3 } Predictors & B (SE B) & P Value \\
\hline Intercept & $0.0004(0.00069)$ & 0.49 \\
Percent Caucasian & $-0.0014(0.00094)$ & 0.13 \\
$\quad$ Population & & \\
Percent of Population & $0.0043(0.0033)$ & 0.20 \\
$\quad$ Born 1945-1965 & $0.78(0.042)$ & $<\mathbf{0 . 0 0 1 *}$ \\
Prevalence of Drug Use & 233 & \\
$\mathrm{~N}$ & 0.71 & \\
$\mathrm{R}^{2}$ & & \\
\hline
\end{tabular}

${ }^{*} P$ values in bold are significant.

B, Coefficient Estimate; SE B, Coefficient - Standard Error; $\mathrm{R}^{2}$, Multiple R-Squared. the nuances of each age group and their current and past behaviors.

\section{Limitations}

This study used publicly available data with data obtained from 1 health care system and, therefore, does not represent the entire population of the study area. Because we are only using data for 1 health care system, we did not have full information for $\mathrm{HCV}$ prevalence. Drug use information included in the EHR did not always specify intravenous as the mode of delivery. Since data for formerly incarcerated and homeless populations are not available at the census tract level, the applicability of the outcomes of this model are limited. Another potential SDOH variable indicating a barrier to $\mathrm{HCV}$ treatment is the requirement that patients with a history of substance use in the last year in North Carolina must be enrolled in a treatment program and agree to abstinence during treatment as well as toxicology screening. 
Table 5. Validation of the Social Determinants of Health Level of Need Index Using Multiple Linear Regression

\begin{tabular}{|c|c|c|}
\hline \multirow[b]{2}{*}{ Predictors } & \multicolumn{2}{|c|}{ Prevalence of Hepatitis C Infection } \\
\hline & $\mathrm{B}(\mathrm{SE} \mathrm{B})$ & $P$ Value* \\
\hline Intercept & $0.0067(0.0018)$ & $<0.001$ \\
\hline Individuals with less than a high school education & $-0.00099(0.0064)$ & 0.87 \\
\hline Households with no/limited English & $-0.024(0.0074)$ & 0.001 \\
\hline Single-parent households & $-0.0074(0.0041)$ & 0.07 \\
\hline Low access to food sources & $-0.000081(0.00056)$ & 0.88 \\
\hline Median household income & $-0.00000035(0.00000019)$ & 0.009 \\
\hline Individuals living below the federal poverty Line & $0.014(0.0054)$ & 0.009 \\
\hline Unemployed individuals & $0.0023(0.0084)$ & 0.79 \\
\hline Uninsured individuals & $0.0078(0.0056)$ & 0.16 \\
\hline Households living in rental housing & $-0.0025(0.0018)$ & 0.17 \\
\hline Households paying $>30 \%$ of income for rent & $-0.0082(0.0044)$ & 0.06 \\
\hline Households without transportation & $0.036(0.0056)$ & $<0.001$ \\
\hline Crowded households ( $>1$ person per room) & $-0.0078(0.013)$ & 0.60 \\
\hline $\mathrm{N}$ & 233 & \\
\hline $\mathrm{R}^{2}$ & 0.50 & \\
\hline
\end{tabular}

${ }^{*} P$ values in bold are significant.

B, Coefficient Estimate; SE B, Coefficient - Standard Error; R², Multiple R-Squared.

In addition, the data analyzed and presented are at the census tract level. Due to the modifiable area unit problem, where the summary statistics of a census tract do not apply to an individual person, the results of our analysis could not be applied to each individual household of the census tract. The data only encompass the central county of a large metropolitan area in the southeast, and therefore, the results may not be applicable to other types of municipalities in the south or other regions of the United States.

\section{Conclusions}

Geospatial models identified a selection of census tracts that can be used to identify populations at risk of HCV infection. Mapping will allow future targeted screening and linkage-to-care interventions for patients at a high risk of HCV. This mapping method is applicable to other regions able to assess regional $\mathrm{SDOH}$ need and $\mathrm{HCV}$ risk variables.

We acknowledge the Social and Economic Team of Atrium Health for their contribution on this project.

To see this article online, please go to: http://jabfm.org/content/ 33/3/407.full.

\section{References}

1. Edlin BR, Eckhardt BJ, Shu MA, Holmberg SD, Swan T. Toward a more accurate estimate of the prevalence of hepatitis $\mathrm{C}$ in the United States. Hepatology 2015;62:1353-63.

2. Hofmeister MG, Rosenthal EM, Barker LK, et al. Estimating prevalence of hepatitis $\mathrm{C}$ virus infection in the United States, 2013-2016. Hepatology 2018;69:1020-31.

3. CDC. Hepatitis $\mathrm{C}$ questions and answers for health professionals. Available from: https://www.cdc.gov/ hepatitis/hcv/hcvfaq.htm. Accessed January 17, 2019.

4. Smith BD, Morgan RL, Beckett GA, et al. Recommendations for the identification of chronic hepatitis $\mathrm{C}$ virus infection among persons born during 1945-1965. MMWR Recomm Rep 2012;61:1-32.

5. Armstrong GL, Wasley A, Simard EP, McQuillan GM, Kuhnert WL, Alter MJ. The prevalence of hepatitis C virus infection in the United States, 1999 through 2002. Ann Intern Med 2006;144:705-14.

6. Rein DB, Wittenborn JS, Weinbaum CM, Sabin M, Smith BD, Lesesne SB. Forecasting the morbidity and mortality associated with prevalent cases of pre-cirrhotic chronic hepatitis $\mathrm{C}$ in the United States. Dig Liver Dis 2011;43:66-72.

7. Wenger PJ, Rottnek F, Parker T, Crippin JS. Assessment of hepatitis $\mathrm{C}$ risk factors and infection prevalence in a jail population. Am J Public Health 2014;104:1722-7.

8. Ha S, Totten S, Pogany L, Wu J, Gale-Rowe M. Hepatitis $C$ in Canada and the importance of risk-based screening. Can Commun Dis Rep 2016;42:57-62. 
9. Akiyama MJ, Kaba F, Rosner Z, et al. Correlates of hepatitis $\mathrm{C}$ virus infection in the targeted testing program of the New York City jail system: epidemiologic patterns and priorities for action. Public Health Rep 2017;132:41-7.

10. Barth H. Hepatitis $\mathrm{C}$ virus: is it time to say goodbye yet? Perspectives and challenges for the next decade. World J Hepatol 2015;7:725-37.

11. El-Serag HB, Kanwal F, Richardson P, Kramer J. Risk of hepatocellular carcinoma after sustained virological response in Veterans with hepatitis $\mathrm{C}$ virus infection. Hepatology 2016;64:130-7.

12. Kanwal F, Kramer J, Asch SM, Chayanupatkul M, Cao Y, El-Serag HB. Risk of hepatocellular cancer in $\mathrm{HCV}$ patients treated with direct-acting antiviral agents. Gastroenterology 2017;153:9961005.e1.

13. Backus LI, Belperio PS, Shahoumian TA, Mole LA. Impact of sustained virologic response with direct-acting antiviral treatment on mortality in patients with advanced liver disease. Hepatology 2019;69:487-97.

14. Tada T, Kumada T, Toyoda H, et al. Viral eradication reduces all-cause mortality, including nonliver-related disease, in patients with progressive hepatitis C virus-related fibrosis. J Gastroenterol Hepatol 2017;32:687-94.

15. CDC. Viral hepatitis surveillance-United States, 2016. Available from: https://www.cdc.gov/hepatitis/ statistics/2016surveillance/index.htm. Accessed January $17,2019$.

16. Kallman JB, Arsalla A, Park V, et al. Screening for hepatitis B, C and non-alcoholic fatty liver disease: a survey of community-based physicians. Aliment Pharmacol Ther 2009;29:1019-24.

17. Ludden TM, Taylor YJ, Simmons LK, et al. Using community-based participatory research to develop geospatial models toward improving community health for disadvantaged hispanic populations in Charlotte, NC. J Primary Prevent 2018;39:171-90.

18. Friedman EE, Dean HD, Duffus WA. Incorporation of social determinants of health in the peerreviewed literature: a systematic review of articles authored by the National Center for HIV/AIDS, Viral Hepatitis, STD, and TB Prevention. Public Health Rep 2018;133:392-412.

19. Daniel H, Bornstein SS, Kane GC; Health and Public Policy Committee of the American College of Physicians. Addressing social determinants to improve patient care and promote health equity: an American College of Physicians position paper. Ann Intern Med 2018;168:577-8.

20. Dulin MF, Tapp H, Smith HA, et al. A trans-disciplinary approach to the evaluation of social determinants of health in a Hispanic population. BMC Public Health 2012;12:769.

21. Bazemore A, Phillips RL, Miyoshi T. Harnessing Geographic Information Systems (GIS) to enable community-oriented primary care. J Am Board Fam Med 2010;23:22-31.

22. Dulin MF, Ludden TM, Tapp H, et al. Using Geographic Information Systems (GIS) to understand a community's primary care needs. J Am Board Fam Med 2010;23:13-21.

23. Dulin MF, Ludden TM, Tapp H, et al. Geographic Information Systems (GIS) demonstrating primary care needs for a transitioning hispanic community. J Am Board Fam Med 2010;23:109-20.

24. Ford MM, Desai PS, Maduro G, Laraque F. Neighborhood inequalities in hepatitis C mortality: spatial and temporal patterns and associated factors. J Urban Health 2017;94:746-55.

25. Edlin BR, Winkelstein ER. Can hepatitis C be eradicated in the United States? Antiviral Res 2014;110:79-93.

26. Dean HD, Fenton KA. Addressing social determinants of health in the prevention and control of HIV/AIDS, viral hepatitis, sexually transmitted infections, and tuberculosis.Public Health Rep 2010;125:1-5.

27. Tohme RA, Xing J, Liao Y, Holmberg SD. Hepatitis $\mathrm{C}$ testing, infection, and linkage to care among racial and ethnic minorities in the United States, 2009-2010. Am J Public Health 2013;103: 112-9.

28. Atrium Health. Mapping social determinants of health. Available from: http://tinyurl.com/SDHStory-Map. Accessed May 12, 2018.

29. Tapp H, Kuhn L, Alkhazraji T, et al. Adapting community based participatory research (CBPR) methods to the implementation of an asthma shared decision making intervention in ambulatory practices. J Asthma 2014;51:380-90.

30. Tapp H, Smith HA, Dixon JT, Ludden T, Dulin M. Evaluating primary care delivery systems for an uninsured Hispanic immigrant population. Fam Community Health 2013;36:19-33.

31. Cooke GS, Hallett TB. HCV and HIV: shared challenges, shared solutions. Lancet Infect Dis 2016;16:755-6.

32. Martin NK, Hickman M, Hutchinson SJ, Goldberg DJ, Vickerman P. Combination interventions to prevent $\mathrm{HCV}$ transmission among people who inject drugs: modeling the impact of antiviral treatment, needle and syringe programs, and opiate substitution therapy. Clin Infect Dis 2013;57:S39-S45.

33. National Academies of Sciences, Committee on a National Strategy for the Elimination of Hepatitis B and C, Board on Population Health and Public Health Practice. A national strategy for the elimination of hepatitis B and C: phase two report. Washington, D.C.: National Academies Press; 2017.

34. Moyer VA, US Preventative Services Task Force. Screening for hepatitis $\mathrm{C}$ virus infection in adults. Ann Intern Med 2013;159:349-57. 
35. Chou RC, Cottrell EB, Wasson N, Rahman B, Guise JM. Screening for hepatitis $\mathrm{C}$ virus infection in adults. Ann Intern Med 2013;158:101-8.

36. Joshi SN. Hepatitis C screening. Ochsner J 2014;14:664-8.

37. Smith BD, Yartel AK. Comparison of hepatitis C virus testing strategies: birth cohort versus elevated alanine aminotransferase levels. Am J Prev Med 2014;47:233-41.

38. Southern WN, Norton B, Steinman M, et al. A birth-cohort testing intervention identified hepatitis c virus infection among patients with few identified risks: a cross-sectional study. BMC Infect Dis 2015;15:553.

39. Klevens RM, Hu DJ, Jiles R, Holmberg SD. Evolving epidemiology of hepatitis $\mathrm{C}$ virus in the United States. Clin Infect Dis 2012;55: S3-9.

40. Noble D, Smith D, Mathur R, Robson J, Greenhalgh T. Feasibility study of geospatial mapping of chronic disease risk to inform public health commissioning. BMJ Open 2012;2:e000711.

41. Iliopoulou P, Tsatsaris A, Katsios I, et al. Risk mapping of visceral leishmaniasis: a spatial regression model for Attica Region, Greece. Trop Med Infect Dis 2018;3:83.

42. Sharif-Askary B, Bittar PG, Farjat A, Liu B, Vissoci J, Allori AC. Geospatial econometric exploration of risk factors for loss to followup in cleft care. Plast Reconstr Surg Glob Open 2018;6:1-2.

43. Lal A. Spatial modelling tools to integrate public health and environmental science, illustrated with infectious cryptosporidiosis. Int J Environ Res Public Health 2016;13:186.

44. Stopka TJ, Goulart MA, Meyers DJ, et al. Identifying and characterizing hepatitis $\mathrm{C}$ virus hotspots in Massachusetts: a spatial epidemiological approach. BMC Infect Dis 2017;17:294.

45. Kauhl B, Heil J, Hoebe CJ, Schweikart J, Krafft T, Dukers-Muijrers NH. The spatial distribution of hepatitis $\mathrm{C}$ virus infections and associated determinants-an application of a geographically weighted Poisson regression for evidence-based screening interventions in hotspots. PLoS One 2015;10: $\mathrm{e} 0135656$.

46. Heil J, Hoebe C, Cals JWL, Ter Waarbeek HLG, van Loo IHM, Dukers-Muijrers N. Detecting hepatitis $\mathrm{B}$ and $\mathrm{C}$ by combined public health and primary care birth cohort testing. Ann Fam Med 2018;16:21-27.

47. U.S. Preventive Services Task Force. Draft recommendation statement: hepatitis $\mathrm{C}$ virus infection in adolescents and adults: screening. Available from: https://www.uspreventiveservicestaskforce.org/Page/ Document/draft-recommendation-statement/ hepatitis-c-screening1. Accessed December 23, 2019. 